\title{
FORTIFIKASI TEPUNG HPI PADA TIK-TIK DAN KUE KERING SEBAGAI MAKANAN TAMBAHAN BALITA
}

\author{
Farida Ariyani*), Sugiyono*), Tazwir*), dan Hangesti Emi Widyasari"')
}

\begin{abstract}
ABSTRAK
Penelitian fortifikasi tepung HPI mujair (Oreochromis mossambica) ke dalam produk camilan cheese stick (tik-tik) dan kue kering untuk makanan tambahan balita telah dilakukan. Jumlah tepung $\mathrm{HPI}$ yang ditambahkan ke dalam tik-tik sebesar 5\%-30\% (b/b). Untuk kue kering sebagai makanan balita, jumlah $\mathrm{HPI}$ yang ditambahkan adalah $10 \%$ dan pada proses pembuatannya ditambahkan pengaroma antara lain strawberry, coklat, dan kayu manis. Pengamatan dilakukan terhadap mutu organoleptik dan kandungan gizinya. Penilaian juga dilakukan pada produk yang sama yang difortifikasi surimi (dibuat dari bahan baku yang sama, yaitu mujair) serta kontrol (tanpa penambahan HPI). Panelis balita adalah siswa-siswi dari Taman Kanak-kanak di Bogor dan Tangerang. Penambahan tepung HPI sampai dengan $15 \%$ pada adonan tik-tik juga disukai panelis dan tingkat kesukaannya sebanding dengan kontrol maupun tik-tik dengan fortifikasi surimi $(P<0.05)$. Kadar protein tik-tik dengan fortifikasi tepung HPI sampai dengan 15\% berkisar $10 \%-14 \%$, sedangkan kadar protein tik-tik tanpa penambahan tepung HPI maupun dengan penambahan surimi berturutturut sebesar $9 \%$ dan $12 \%$. Tingkat penerimaan balita terhadap kue kering hasil fortifikasi HPI $(10 \%)$ yang dibuat dengan berbagai rasa sebanding dengan kue kering tanpa penambahan $\mathrm{HPI}$ $(P>0,05)$ baik dari segi rupa, tekstur, aroma maupun rasa. Meskipun kenaikan kadar protein kue balita hasil fortifikasi HPI tidak terlalu mencolok apabila dibandingkan dengan kontrol, penambahan tepung $\mathrm{HPI}$ tersebut memberikan pengaruh positif pada proporsi asam aminonya.
\end{abstract}

ABSTRACT: Fortification of fish protein hydrolysates powder into snacks for children. By: Farida Ariyani, Sugiyono, Tazwir, and Hangesti Emi Widyastuti.

Fortification of fish protein hydrolysates (FPH) powder from tilapia (Oreochromis mossambica) on snack sproduct, i.e. cheese stick (tik-tik) and biscuit for children under 5-years-olds was carried out. The amount of FPH powder added to cheese stick was 5\% to $30 \%$ (w/w). While that for biscuits, was $10 \%$ (W/W). During process, straw berry, chocolate and cinnamon flavors were added. Evaluation was conducted for organoleptic quality and nutrition content. The assessment was also carried out on the same product both fortified by tilapia surimi and without addition of FPH. Panelists for biscuits were pre-school children in Bogor and Tangerang. The addition of FPH powder up to $15 \%$ on cheese stick dough, was preferend by panelists and the level of perference was comparable to control as well as for cheese stick fortified with tilapia mince $(P<0.05)$. Protein content of the cheese stick fortified by FPH up to $15 \%$ was $10 \%-14 \%(w / W)$, while the protein content of those cheese stick without addition of FPH and fortified by surimi were $9 \%$ and $12 \%(W / W)$ respectively. The preference of pre-school children on the biscuits fortified by $\mathrm{FPH} 10 \%(\mathrm{~W} / \mathrm{W})$ with various tastes was comparable with those without addition of $\mathrm{FPH}(P>0.05)$, either from appearance, aroma or taste. Although the increment of protein content on biscuits fortified by FPH was not so high compared to control, the addition of FPH on the biscuits resulted in positive effect on the amino acid proportions

KEYWORDS: FPH, fortification, snack, children

\section{PENDAHULUAN}

Kekurangan gizi anak di Indonesia merupakan masalah serius yang harus segera di atasi mengingat sekitar 10,8\% anak-anak di Indonesia menderita kurang gizi dan gizi buruk terutama di daerah tertinggal. Masalah gizi yang paling banyak dihadapi adalah kurang kalori protein (KKP) yang pada umumnya menimpa anak usia balita (Karyadi dalam Sulaeman, 1994). Hal ini menuntut tersedianya berbagai jenis makanan bergizi dan berdaya cerna tinggi yang dapat dipenuhi antara lain melalui fortifikasi makanan dengan bahan-bahan yang memenuhi persyaratan. Salah satu bahan sumber protein yang dapat digunakan untuk fortifikasi adalah hidrolisat protein ikan (Meredith et al., 1989).

Hidrolisat protein ikan (HPI) mempunyai sifat fungsional yang lebih baik daripada tepung ikan maupun konsentrat protein ikan, antara lain mempunyai kelarutan yang sangat tinggi dan kelarutan ini tidak banyak berubah walaupun mendapat perlakuan suhu tinggi misalnya pada proses sterilisasi mampu bertahan dalam bentuk cair pada konsentrasi

\footnotetext{
Peneliti pada Balai Penelitian Perikanan Laut

${ }^{\star \star}$ ) Mahasiswa Fakultas Perikanan, IPB
} 
tinggi (Frokjaer, 1994; Lahl \& Steven, 1994). Dari beberapa penelitian di Jepang, diketahui bahwa penggunaan hidrolisat protein ikan tidak terbatas hanya sebagai penyedap, tetapi secara luas digunakan untuk sup minuman berprotein tinggi, biskuit, saus, dan sebagainya (Barzana \& Garcia-Garibay, 1994). Menurut Venugopal (1994), hidrolisat protein ikan juga berguna sebagai bahan pengganti susu, untuk suplementasi produk makanan olahan seperti serealia, roti, serta krupuk.

Hasil perikanan Indonesia seperti ikan bernilai ekonomis rendah belum dimanfaatkan secara optimal. Produksi ikan bernilai ekonomis rendah seperti tembang, petek, dan mujair cukup tinggi, yaitu 157.105, 71.401, dan 16943 ton (Anonim, 1998). Pada umumnya, ikan bernilai ekonomis rendah tersebut hanya dimanfaatkan sebagai bahan baku ikan asin dan tepung ikan. Pada dasarnya ikan-ikan tersebut dapat diolah menjadi bahan yang mempunyai nilai ekonomis lebih, seperti halnya HPI. Dengan pemanfaatan ikan bernilai ekonomis rendah sebagai HPI, maka akan menaikkan nilai tambah ikan-ikan tersebut sekaligus dapat meningkatkan penyediaan bahan pangan berprotein tinggi. Penelitian terdahulu menunjukkan bahwa mujair dapat diolah menjadi tepung hidrolisat protein ikan dengan kadar protein cukup tinggi dan susunan asam amino yang cukup berimbang (Ariyani et al., 1999, Tazwir et al., 2000)

Penelitian ini bertujuan untuk menjajaki kemungkinan pemanfaatan tepung HPI yang berasal dari ikan mujair sebagai bahan untuk fortifikasi produk camilan tik-tik maupun kue kering untuk makanan tambahan balita

\section{BAHAN DAN METODE}

\section{Bahan dan Metode}

\section{Tik-tik}

Bahan yang digunakan untuk fortifikasi adalah tepung HPI dari ikan mujair, hasil hidrolisis secara enzimatis menggunakan enzim papain kasar 10\% selama lima hari pada suhu $55^{\circ} \mathrm{C}$ dan dikeringkan menggunakan spray drier dengan bahan pengisi dekstrin (Ariyani et al., 1999). Tepung HPI yang digunakan dalam penelitian ini berkadar protein $43 \%$ $44 \%$ serta berkadar garam tinggi $(21 \%-23 \%)$ yang berasal dari garam yang terdapat pada enzim papain (Tazwir et al., 2000). Adapun bahan untuk pembuatan tik-tik adalah tepung terigu, tepung tapioka, garam, air, kuning telur (sebagai pewarna), putih telur, mentega, dan rumbutter dengan proses pembuatan seperti yang dilakukan oleh Peranginangin, et al. (1998).
Untuk fortifikasi tik-tik, proporsi tepung HPI yang ditambahkan bervariasi yaitu $5 \%, 10 \%, 15 \%, 20 \%$, $25 \%$, dan $30 \%$. Pengamatan dilakukan terhadap mutu organoleptik dan kandungan gizinya yaitu proksimat dan asam aminonya. Penilaian juga dilakukan pada produk yang sama tanpa penambahan tepùng HPI (kontrol), maupun dengan penambahan surimi $18 \%$ (dibuat dari bahan baku yang sama, yaitu mujair

\section{Kue kering}

Bahan yang digunakan untuk fortifikasi sama dengan bahan untuk fortifikasi tik-tik, yaitu tepung HPI dari ikan mujair, sedangkan bahan untuk pembuatan kue kering adalah tepung terigu, garam, telur, mentega, susu skim, maizena serta gula. Prinsip dasar pembuatan kue kering adalah pencampuran bahan, penipisan adonan, pencetakan dan pemanggangan pada suhu $180^{\circ} \mathrm{C}-190^{\circ} \mathrm{C}$ selama kurang lebih 30 menit. Pada pelaksanaan fortifikasi tepung HPI pada kue kering untuk makanan balita dilakukan dua tahap. Tahap pertama merupakan penelitian pendahuluan untuk memilih proporsi tepung $\mathrm{HPI}(5 \%-20 \%)$ yang tepat yang ditambahkan pada adonan kue Untuk tahap pertama, evaluasi hanya dilakukan secara sensori dengan panelis orang dewasa menggunakan lembar penilaian kesukaan dengan skala 1-9. Pada tahap ke dua dilakukan pembuatan kue kering dengan fortifikasi tepung HPI yang terpilih pada tahap pertama dengan beberapa jenis rasa antara lain rasa strawberry, kayu manis, dan coklat. Selain itu juga dibuat kue kering yang sama tanpa penambahan tepung HPI maupun pengaroma sebagai kontrol. Panelis pada tahap ke dua ini adalah balita dari TK di Bogor dan Tangerang. Dalam pelaksanaannya, evaluasi sensoris oleh balita dilakukan satu per satu dengan didampingi orang dewasa menggunakan lembar penilaian yang lebih sederhana, yaitu skala kesukaan dengan level 1-5

Seperti halnya produk tik-tik, selain mutu organoleptiknya, juga dilakukan analisis gizinya antara lain kadar air dan abu dengan metode gravimetri, protein dengan metode Kjeldahl, lemak dengan metode Soxhlet (AOAC, 1984) serta asam amino.

Data hasil analisis diolah secara statistik dengan disain acak lengkap menggunakan program paket Siricheae.

\section{HASIL DAN BAHASAN}

\section{Tik-tik}

Secara organoleptik, hasil penilaian panelis terhadap penampakan maupun warna pada tik-tik menunjukkan bahwa penambahan tepung HPI pada 

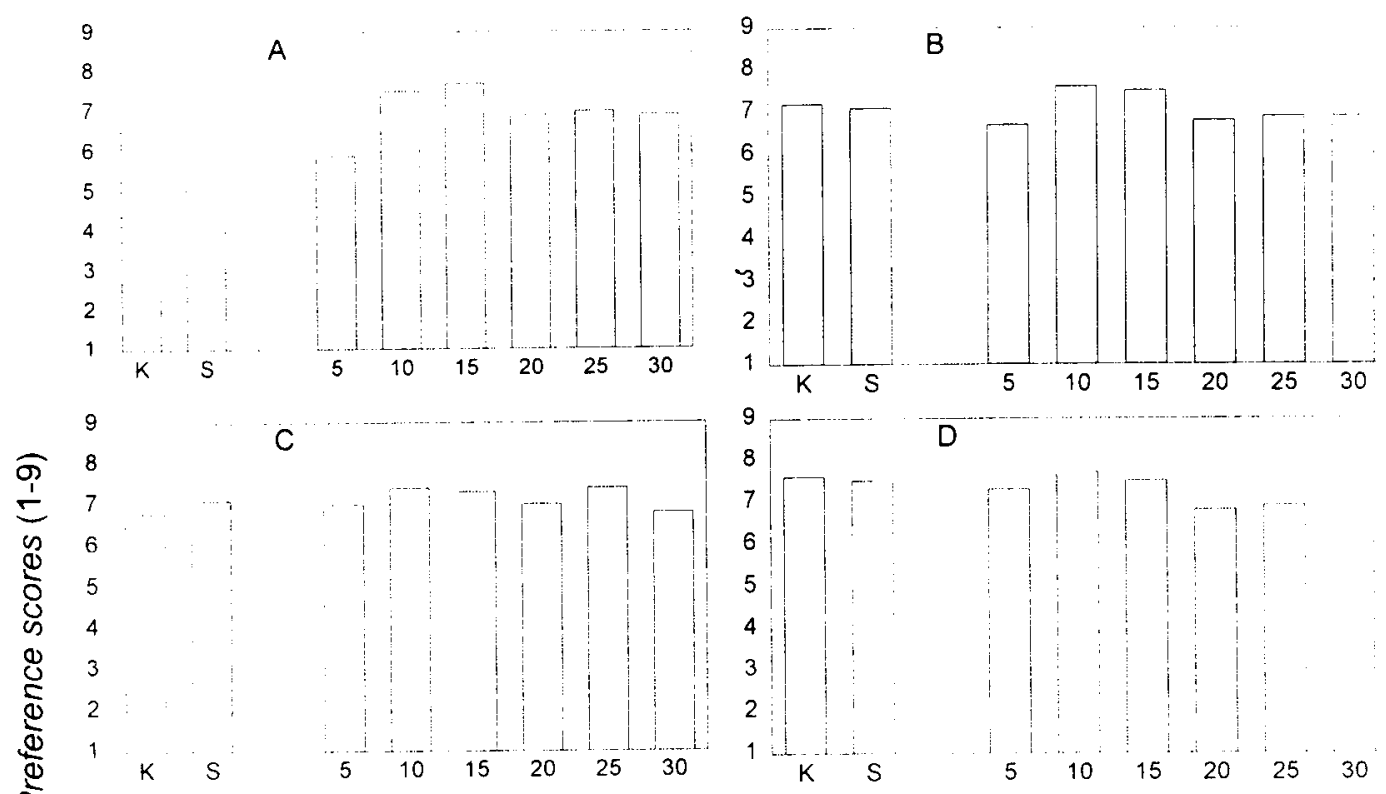

D

E

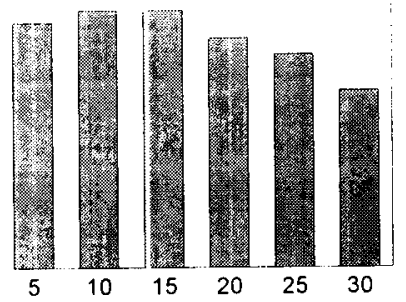

A: rupa/appearance

B: warna/colour

C: aromalodour

D: teksturitexture

E: rasa/taste

$\mathrm{K}$ : kontrol/control.

$\mathrm{S}$ : surimi/surimi

Konsentrasi HPI/FPH concentration (\%)

Gambar 1. Nilai kesukaan panelis terhadap tik-tik

Figure 1. Preference scores of tik-tik

tik-tik tidak memberikan perbedaan warna yang terlalu mencolok dan secara statistik tidak berbeda nyata $(P>0,05)$ meskipun penambahannya cukup besar, yaitu $30 \%$. Demikian juga dengan aroma tiktik, penambahan berbagai konsentrasi tepung HPI tidak memberikan pengaruh nyata pada nilai kesukaannya. $(P>0,05)$ dan penambahan tepung $\mathrm{HPI}$ sampai dengan $30 \%$ memberikan nilai kesukaan yang sebanding dengan kontrol maupun tik-tik dengan fortifikasi surimi. Hal ini menunjukkan bahwa aroma amis yang biasanya menyertai produk perikanan tidak terdeteksi dalam tik-tik, karena panelis sudah terbiasa dengan aroma tik-tik yang dibuat dengan campuran keju.

Sedikit berbeda dengan nilai penampakan dan aroma tik-tik, penilaian terhadap tekstur menunjukkan bahwa penambahan tepung HPI sampai dengan $15 \%$ sebanding dengan kontrol maupun tik-tik dengan fortifikasi surimi; sebaliknya penambahan tepung HPI sebanyak 20\%-30\% ternyata menurunkan nilai penerimaan (Gambar 1). Hal ini disebabkan karena teksturnya yang cenderung keras sejalan dengan peningkatan jumlah protein maupun karbohidrat dalam adonan (dari dekstrin sebagai bahan pengisi tepung $\mathrm{HPI}$ ) dengan semakin tingginya jumlah tepung HPI yang ditambahkan.

Pola penerimaan panelis terhadap rasa tik-tik juga hampir sama dengan pola penerimaan terhadap tekstur, yaitu penambahan tepung HPI sampai dengan $15 \%$ sebanding dengan kontrol maupun tiktik dengan fortifikasi surimi, sedangkan kenaikan penambahan tepung HPI lebih dari $15 \%$ cenderung menurunkan penilaian terhadap rasa. Kenyataan ini disebabkan karena rasa yang semakin asin dengan semakin tingginya jumlah tepung HPI yang ditambahkan ke dalam adonan tik-tik. Pada umumnya produk hidrolisat protein berasa pahit karena adanya senyawa peptida berantai pendek (Aubes-Dufaus et al., 1995), akan tetapi dalam penelitian in rasa pahit HPI tidak terlampau mencolok karena telah tertutup oleh rasa asin yang berasal dari enzim papain ('paya') yang digunakan untuk menghidrolisis daging ikan (Ariyani et al., 1999), sehingga rasa asin tersebut terbawa pada produk 


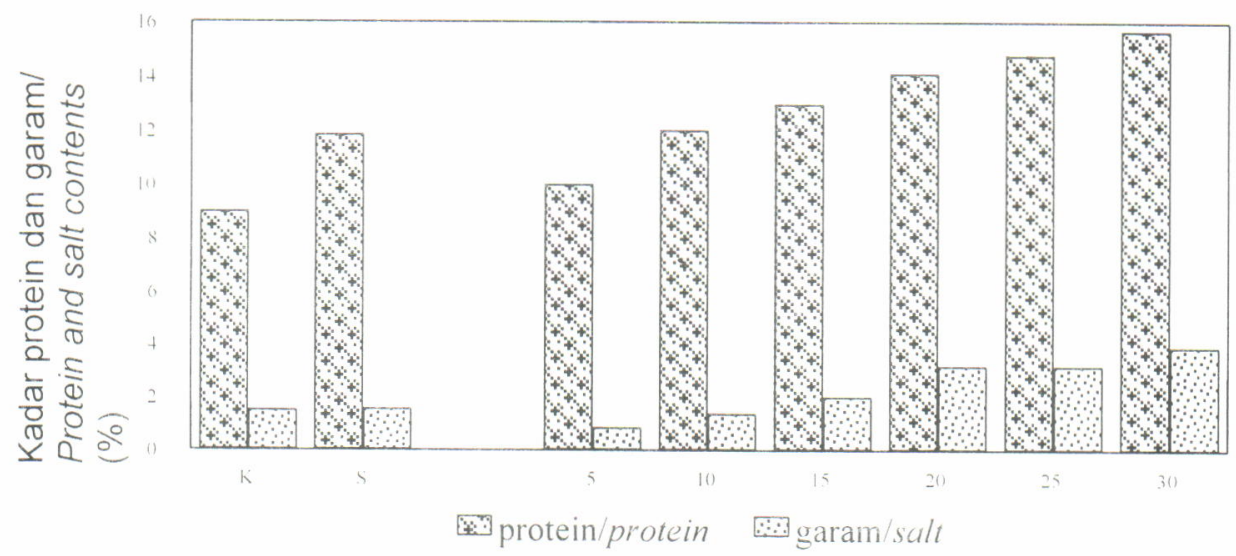

Konsentrasi HPI/FPH concentration (\%) $\mathrm{K}=\mathrm{kontrol} /$ control $\mathrm{S}=$ surimi/surimi

Gambar 2. Kadar protein dan garam tik-tik hasil fortifikasi HPI, surimi dan kontrol Figure 2. Protein and salt contents of tik-tik fortified by FPH, surimi and control

hasil fortifikasinya. Meskipun demikian beberapa panelis dapat mendeteksi rasa pahit tersebut terutama untuk tik-tik dengan penambahan tepung $\mathrm{HPl}$ yang tinggi (25\% dan 30\%). Beberapa panelis memberikan komentar adanya rasa 'gurih' pada tiktik hasil fortifikasi HPI. Hal ini dapat dimengerti karena salah satu produk hidrolisis protein ikan adalah oligopeptida yang mempunyai proporsi molaritas yang tinggi dari asam glutamat (Noguchi et al. dalam Barzana \& Garcia-Garibay 1994)

Berdasarkan penerimaan total terhadap tik-tik, perbedaan penilaian antara tik-tik hasil fortifikasi tepung HPI dengan kontrol maupun tik-tik hasil fortifikasi surimi hampir tidak terlihat secara nyata ( $P>0,05)$ kecuali tik-tik dengan fortifikasi tepung HPI sebanyak $30 \%$. Penolakan panelis terhadap tik-tik dengan penambahan tepung HPI sebanyak 30\% lebih disebabkan rasanya yang terlalu asin dan teksturnya yang agak keras dan bukan karena warnanya

Berdasarkan hasil analisis kimia, kadar protein tik-tik meningkat dengan semakin besarnya jumlah tepung HPI yang ditambahkan, demikian juga dengan kadar garamnya (Gambar 2). Dibandingkan dengan kontrol, kadar protein tik-tik hasil fortifikasi HPI dengan berbagai konsentrasi semuanya lebih tinggi secara nyata $(P<0.05)$, sedangkan apabila dibandingkan dengan tik-tik hasil fortifikasi surimi, kadar protein tik-tik hasil fortifikasi HPI 10\% tidak berbeda nyata. Perbedaan kadar protein tik-tik hasil fortifikasi HPI dengan tik-tik hasil fortifikasi surimi terlihat pada penambahan HPI 15\% atau lebih. Hal ini memperlihatkan bahwa pada kadar tepung $\mathrm{HPI}$ yang lebih kecil dari surimi (HPI 10\% bobot basah atau $10.51 \%$ bobot kering dan surimi $18 \%$ bobot basah atau $32,73 \%$ bobot kering) memberikan efek penambahan protein dalam tik-tik yang sama. Ini berarti bahwa penambahan tepung HPI lebih efektif dalam menaikkan kadar protein tik-tik dibandingkan dengan surimi, karena HPI merupakan bahan pangan berkadar protein tinggi (isolat protein).

Peningkatan kadar garam pada tik-tik disebabkan karena peningkatan jumlah garam dalam adonan yang berasal dari penambahan tepung $\mathrm{HPI}$ yang semakin meningkat mengingat tepung $\mathrm{HPI}$ mengandung garam cukup tinggi, yaitu sebesar $21 \%$ $23 \%$. Kadar garam tik-tik hasil fortifikasi HPI 10\% tidak berbeda nyata dengan kadar garam tik-tik hasil fortifikasi surimi maupun kontrol $(P<0,05)$. Penambahan tepung HPI sebanyak $15 \%$ atau lebih ternyata meningkatkan kadar garam tik-tik secara nyata dan penambahan HPI dengan konsentrasi tertinggi (30\%) memberikan kenaikan kadar garam tertinggi pada tik-tik yaitu $4 \%$.

Di samping kadar protein dalam produk, penentuan produk terbaik/terpilih juga harus mempertimbangkan tingkat penerimaan panelis. Dari hasil evaluasi sensoris, terlihat bahwa rasa asin merupakan salah satu faktor penyebab ketidaksukaan panelis, dan rasa asin ini paralel dengan kadar garam dalam tik-tik. Dengan demikian kadar garam merupakan faktor pembatas dalam pemilihan produk terbaik. Karena salah satu tujuan fortifikasi tik-tik dengan HPI adalah untuk meningkatkan kadar proteinnya, maka kadar protein tik-tik juga merupakan faktor pembatas dalam penentuan produk terpilih. Dengan mempertimbangkan faktor pembatas tersebut, maka dapat dinyatakan bahwa penambahan tepung HPI pada fortifikasi tik-tik yang optimal adalah 15\%. Proporsi tepung HPI optimal yang 
Tabel 1. Komposisi asam amino tik-tik hasil fortifikasi HPI dan kontrol

Table 1. Amino acid composition of tik-tik fortified by FPH and control

\begin{tabular}{lcc}
\hline \multicolumn{1}{c}{$\begin{array}{c}\text { Asam amino } \\
\text { Amino acids }\end{array}$} & $\begin{array}{c}\text { Kontrol (mg/100g bahan) } \\
\text { Control (mg/100g sample) }\end{array}$ & $\begin{array}{c}\text { Fortifikasi HPI 15\% } \\
\text { (mg/100g bahan) } \\
\text { Fortified by 15\% FPH } \\
\text { (mg/100g samp/e) }\end{array}$ \\
\hline Asam aspartat (Aspartic acid) & 0.11 & 0.25 \\
Asam glutamat (Glutamic acid) & 0.09 & 0.10 \\
Serin (Serine) & 0.23 & 0.20 \\
Arginin (Arginine) & 0.02 & 0.09 \\
Treonin (Threonine) & 0.13 & 0.29 \\
Alanin (Alanine) & 0.14 & 0.21 \\
Tirosin (Tyrosine) & 0.05 & 0.02 \\
Valin (Valine) & 0.03 & 0.05 \\
Sistein (Cystein) & 0.31 & 0.33 \\
Lisin (Lysine) & 0.18 & 0.16 \\
Total & 1.29 & 1.70 \\
\hline
\end{tabular}

ditambahkan dalam tik-tik ini masih lebih tinggi dibandingkan dengan jumlah optimal tepung HPI yang ditambahkan dalam pembuatan kerupuk (Yu \& Tan dalam Barzana \& Garcia-Garibay, 1994). Sedangkan Murdinah et al. (1996) menyatakan bahwa penambahan protein konsentrat limbah kakap merah yang optimal pada camilan hasil ekstrusi adalah $10 \%$.

Hasil analisis asam amino menunjukkan bahwa meskipun tidak semua jenis asam amino mengalami kenaikan pada tik-tik hasil fortifikasi HPI, total asam amino tik-tik hasil fortifikasi HPI lebih tinggi apabila dibandingkan dengan tik-tik tanpa penambahan HPI (Tabel 1). Sebanyak 7 jenis (dari 10 jenis) asam amino pada tik-tik terpilih mempunyai proporsi yang lebih tinggi dibanding kontrol. Hal ini memperlihatkan bahwa penambahan tepung HPI pada adonan tik-tik sebanyak $15 \%$ memberikan kenaikan pada beberapa jenis asam aminonya, maupun total asam aminonya

\section{Kue kering}

Hasil penelitian pendahuluan kue kering manis menunjukkan bahwa penerimaan panelis terhadap kue kering hasil fortifikasi HPI 10\% sebanding atau lebih disukai dari kontrol maupun kue hasil fortifikasi surimi (Gambar 3). Berdasarkan aroma maupun rasa, kue kering tanpa penambahan tepung $\mathrm{HPI}$ (kontrol) memperoleh nilai kesukaan paling tinggi

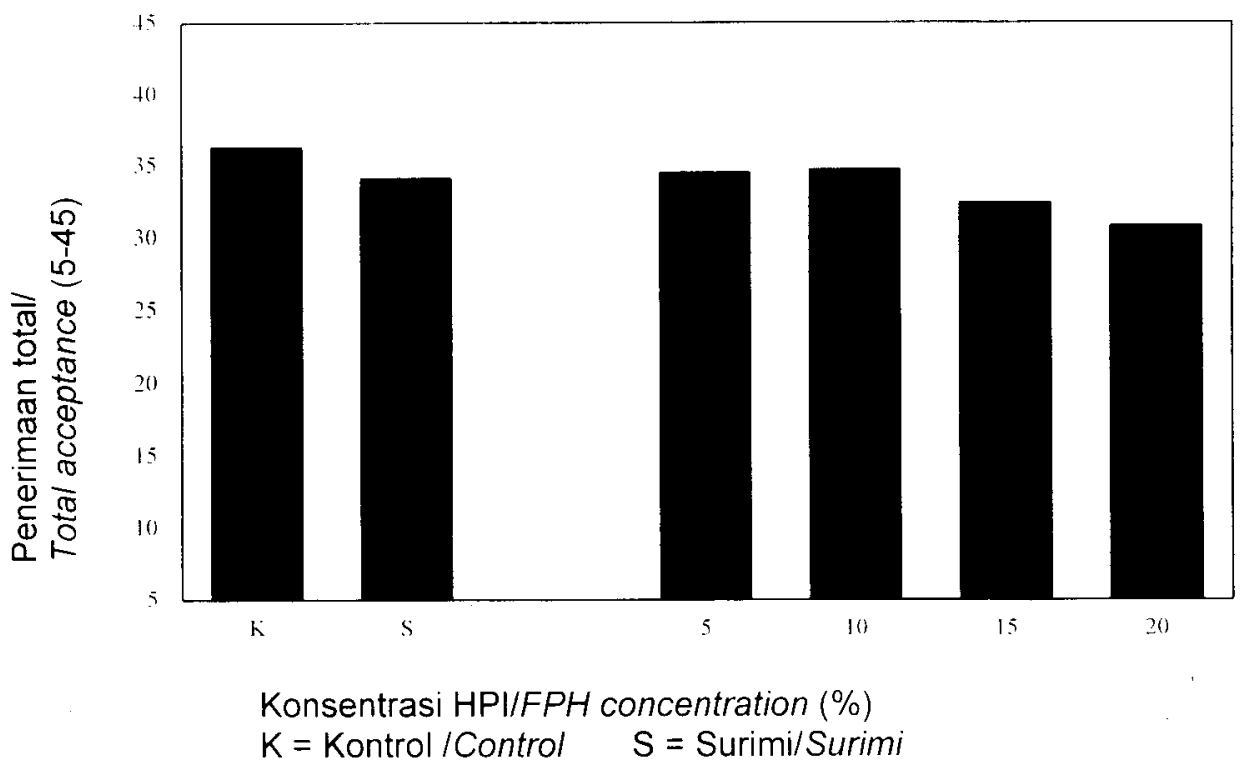

Gambar 3. Nilai penerimaan total panelis terhadap kue kering manis (pendahuluan)

Figure 3. Total acceptance scores of sweet biscuit (preliminary trial) 
dibandingkan dengan lainnya sedangkan fortifikasi tepung HPI sampai 10\% sebanding dengan kue kering hasil fortifikasi surimi. Menurut Yu \& Kaur (1991), fortifikasi tepung ikan layang sebanyak 16\% pada biskuit dapat diterima oleh panelis. Penerimaan paling rendah pada penelitian ini diperoleh kue hasil fortifikasi tepung HPI 20\%. Sedikit berbeda dengan tik-tik, penambahan tepung $\mathrm{HPI}$ dalam jumlah yang sama pada tik-tik (15\%) apabila diaplikasikan pada kue kering sudah menurunkan nilai penerimaan panelis secara nyata $(P<0,05)$. Kenyataan ini disebabkan karena kue kering ini sifatnya manis sehingga kenaikan jumlah garam (dari kenaikan jumlah tepung $\mathrm{HPI}$ yang ditambahkan) yang relatif sedikit sudah cukup menurunkan mutu organoleptiknya. Dengan demikian fortifikasi tepung HPI sebanyak $10 \%$ digunakan untuk studi selanjutnya.

Pada studi selanjutnya yang menggunakan balita sebagai panelis, hasil penilaian organoleptik kue (dengan penambahan tepung HPI 10\%) menunjukkan bahwa tingkat penerimaan balita terhadap rupa, tekstur maupun rasa kue yang difortifikasi HPI tidak berbeda nyata dengan kontrol, sedangkan berdasarkan aromanya, kue dengan rasa strawberry maupun kontrol mendapatkan nilai lebih tinggi dari kue dengan rasa coklat maupun kayu manis (Gambar 4). Meski- pun demikian, hasil penerimaan total ke empat jenis kue tersebut tidak berbeda nyata $(P>0,05)$. Hal ini sejalan dengan Charoenphol et al. (1988) yang menyatakan bahwa penambahan tepung ikan pada level 5\%-12\% disukai oleh anak pra sekolah. Pencetakan kue dalam bentuk yang menarik (bebek, ikan. bintàng) pada penelitian ini diduga mengakibatkan tingginya tingkat penerimaan balita pada penampakan dan tidak memberikan perbedaan nyata dengan kontrol.

Penambahan tepung HPI pada kue tidak memberikan perbedaan tingkat penerimaan balita terhadap rasa kue. Hal ini kemungkinan disebabkan karena rasa asin dan pahit dari tepung HPI tertutup oleh bahan pengaroma yang ditambahkan seperti esens strawberry, coklat, dan kayu manis. Di samping itu rasa 'gurih' dari HPI yang biasanya dijumpai pada produk hasil hidrolisis protein ikan ((Noguchi et al. dalam Barzana \& Garcia-Garibay, 1994) juga turut berperan dalam menutup rasa pahit maupun asin pada kue kering hasil fortifikasi HPI. Namun demikian, tingkat penerimaan balita terhadap kue hasil fortifikasi tepung HPI kemungkinan bukan disebabkan karena balita dapat mentolerir rasa $\mathrm{HPI}$ pada kue tersebut, akan tetapi lebih disebabkan karena penampakan yang menarik serta rasa dan

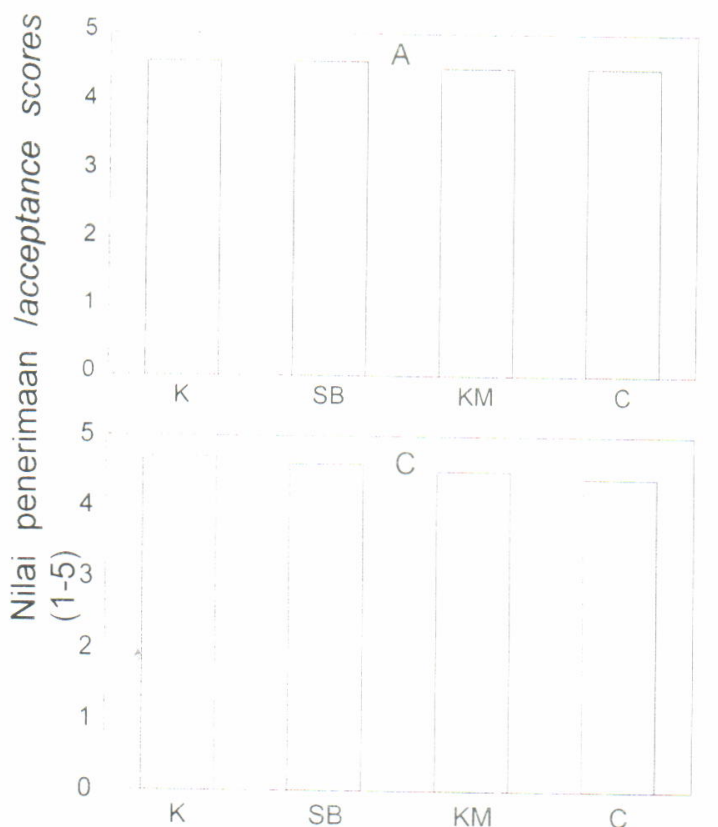

A: Penampakan/Appearance

B: Aroma/Odour

C: Tekstur/Texture

D: Rasa/Taste
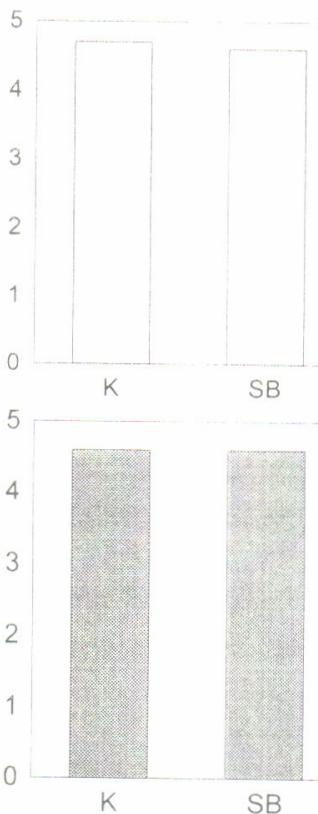

K: Kontrol/Control
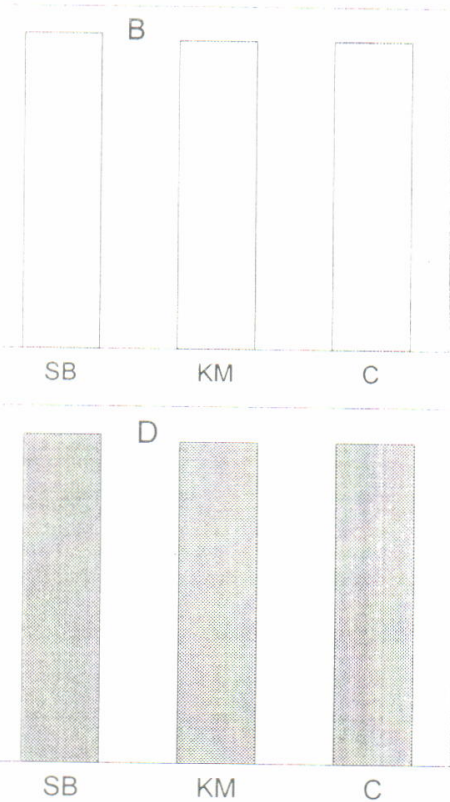

SB: Strawberi/Strawberry

KM: Kayu manis/Cinnamon

C. Coklat/Chocolate

Jenis kue kering manis/Kinds of sweet biscuits

Gambar 4. Nilai penerimaan kue kering manis oleh balita

Figure 4. Acceptance scores of sweet biscuits evaluated by pre-school children 


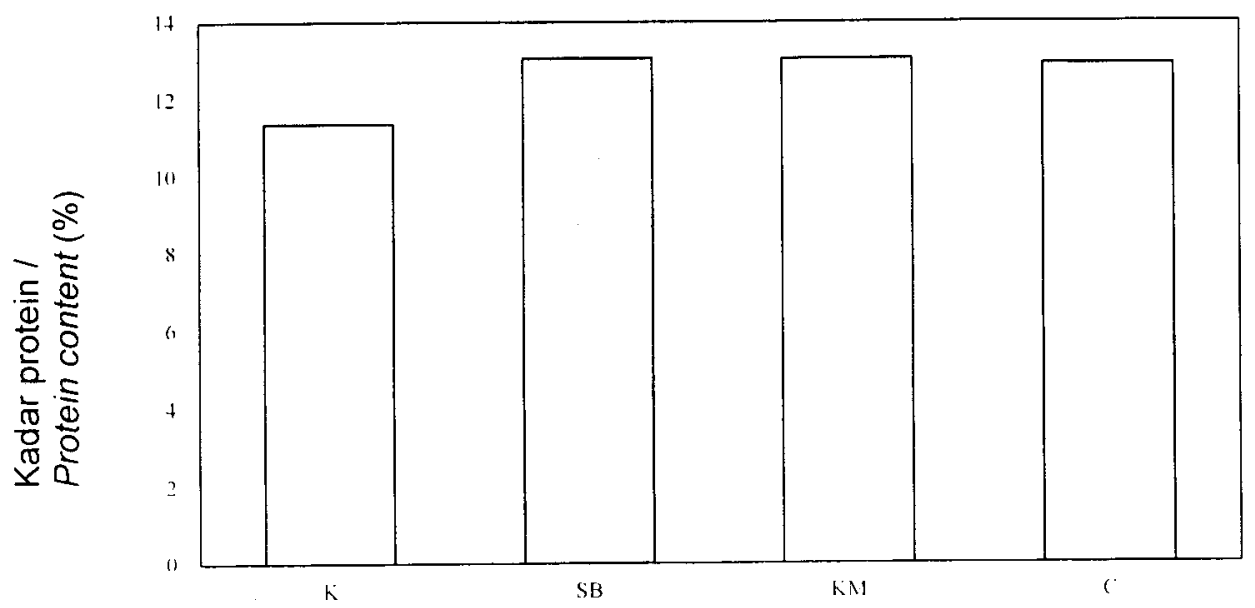

Jenis kue kering manis/Kinds of sweet biscuits $\mathrm{K}=\mathrm{Kontrol} /$ Control, $\mathrm{SB}=$ Straw beri/Straw berry, $\mathrm{KM}=$ Kayu manis $/$ Cinnamon

Gambar 5. Kadar protein kue kering manis

Figure 5. Protein content of sweet biscuit

aroma dari bahan pengaroma yang ditambahkan ke dalam adonan. Hal ini tidak menjadi masalah karena tujuan utamanya adalah agar balita dapat menerima kue hasil fortifikasi HPI sebanding (tidak dapat membedakan) dengan kue tanpa penambahan HPI.

Berdasarkan kadar proteinnya, kue kering hasil fortifikasi HPI dengan berbagai rasa mempunyai kadar protein yang berbeda dengan kontrol akan tetapi tidak ada perbedaan antar berbagai rasa kue. Pada Gambar 5 terlihat bahwa kadar protein kue kering hasil fortifikasi HPI lebih tinggi dari kontrol. Kenyataan ini juga terefleksi pada kenaikan total asam amino maupun proporsi beberapa jenis asam aminonya (Tabel 2).

Tabel 2. Komposisi asam kue kering manis hasil fortifikasi HPI dan kontrol Table 2. Amino acid composition of biscuit fortified by FPH and control

\begin{tabular}{|c|c|c|}
\hline $\begin{array}{l}\text { Asam amino } \\
\text { Amino acids }\end{array}$ & $\begin{array}{l}\text { Kontrol (mg/100g bahan) } \\
\text { Control (mg/100g sample) }\end{array}$ & $\begin{array}{c}\text { Fortifikasi HPI } 15 \% \\
\text { (mg/100g bahan) } \\
\text { Fortified by } 15 \% \text { FPH } \\
\text { (mg/100g sample) }\end{array}$ \\
\hline Asam aspartat (Aspartic acid) & 0.07 & 0.01 \\
\hline Asam glutamat (Glutamic acid) & 0.32 & 1.63 \\
\hline Serin (Serine) & 0.02 & 0.10 \\
\hline Glisin (Glycine) & 0.94 & $\mathrm{ttd} / \mathrm{nd}^{*}$ \\
\hline Histidin (Histidine) & 0.26 & 0.44 \\
\hline Arginin (Arginine) & 0.02 & 2.47 \\
\hline Treonin (Threonine) & 0.22 & $\mathrm{ttd} / \mathrm{nd}^{\star}$ \\
\hline Alanin (Alanine) & 0.35 & 2.71 \\
\hline Prolin (Proline) & 0.04 & 0.65 \\
\hline Tirosin (Tyrosine) & $\mathrm{ttd} / \mathrm{nd}^{\star}$ & 0.01 \\
\hline Valin (Valine) & 0.61 & 0.96 \\
\hline Metionin (Methionine) & 1.07 & $\mathrm{ttd} / \mathrm{nd}^{*}$ \\
\hline Sistein (Cystein) & 0.74 & 1.19 \\
\hline Lisin (Lysine) & $\mathrm{ttd} / \mathrm{nd}^{*}$ & 1.46 \\
\hline Fenilalanin (Phenylalanine) & $\mathrm{ttd} / \mathrm{nd}^{\star}$ & 0.08 \\
\hline Total & 4.66 & 11.71 \\
\hline
\end{tabular}

${ }^{*} \mathrm{ttd}=$ tidak terditeksi $n d=$ not detected 


\section{KESIMPULAN}

Dengan mempertimbangkan hasil penelitian di atas, dapat diambil kesimpulan bahwa

1. Tepung HPI dapat digunakan sebagai bahan untuk fortifikasi camilan tik-tik maupun kue kering untuk makanan tambahan balita.

2. Penambahan tepung $\mathrm{HPI}$ yang optimal pada tiktik adalah 15\%. Dengan penambahan tersebut, penerimaan tik-tik oleh panelis sebanding dengan kontrol dan dapat meningkatkan kadar protein sebanyak $4 \%$ dengan proporsi asam amino yang lebih tinggi dari kontrol.

3. Tingkat penerimaan anak-anak balita pada kue kering yang telah difortifikasi HPI 10\% sebanding dengan kontrol. Kadar protein kue kering yang difortifikasi HPI 10\% adalah 13\%

4. Rasa asin tepung HPI merupakan kendala dalam penggunaannya sebagai bahan fortifikasi camilan, sehingga disarankan untuk memilih camilan yang sifatnya asin dan gurih seperti kue keju, camilan hasil ekstrusi (chiki) dan sebagainya.

\section{UCAPAN TERINIA KASIH}

Terima kasih penulis sampaikan kepada Dian Wijanarko S.Pi. atas bantuannya dalam analisis kimia tik-tik, juga kepada Trisilo Bambang S.W., S.Pi. atas bantuannya dalam analisis statistik.

\section{DAFTAR PUSTAKA}

AOAC 1994. Official Methods of Analysis. $15^{\text {th }}$ ed. Helrich, K. (ed.). Washington, D.C.: AOAC, $27 \mathrm{pp}$

Ariyani, F., Saleh, M., Tazwir dan Haq, N. 1999. Penelitian kondisi optimal pembuatan HPI secara ensimatis. Laporan Teknis Penelitian. Preparasi Hidrolisat Protein Ikan (HPI) sebagai Bahan Fortifikasi Pangan. Jakarta: Instalasi Penelitian Perikanan Laut Slipi, Balai Penelitian Perikanan Laut, Puslitbangkan, p.1-74

Aubes-Dufau, I., Seris, J, and Combes, D. 1995. Production of peptic hemoglobin hydrolysates: Bitterness demonstration and characterization. J. Agric. Food Chem. 43: 1982-1988

Barzana, E. and Garcia-Garibay, N. 1994. Production of fish protein concentrate. In Martin, A.M. (ed.) Fisher- ies Processing: Biotechnology Applications. London, Chapman \& Hall. p.207-222.

Charoenphol, C., Yaowala-ong, M., Wacharangkul, P. Poarrimoung, S., Silapaphrom, S. and Srichaiya, C 1988. Processed supplementary food from fish powder. Proceeding of IPFC Working Party on Fish Technology and Marketing, Bangkok, Thailand, 19-22 April 1988. Rome: FAO. p.252-259

Frokjaer, S. 1994. Use of hydrolysate for protein supplement. Food Technology: 86-88.

Lahl, W.J. and Steven, D.B. 1994. Enzymatic production of protein hydrolysate for food use. Food Technology: p.69-71

Meredith, C.N. Zackin, M.J., Frontera, W.R. and Evans W.J., 1989. Dietery protein requirement and body protein metabolism in endurance-trained men. J. App. Physiol. 66: 2850-2856.

Murdinah, Suparno, Saleh, M. and Setyani, A. 1996. Use of protein concentrate from recovered fish meat for extruded food products. Proceeding of IPFC Working Party on Fish Technology and Marketing, Colombo, Sri Lanka, 4-7 June 1996. Rome: FAO: 287-291.

Peranginangin, R., Sugiyono, Fawzya, $Y, N$. dan Retnowati, N. (1998). Teknologi fortifikasi protein ikan pada makanan camilan tik-tik dan kue ikan. Seri Informasi Pascapanen Perikanan No.: 41. Jakarta: Instalasi Penelitian Perikanan Laut Slipi, Balitkanlut. Jakarta, $8 \mathrm{pp}$

Sulaeman, A. 1994. Makanan Balita dan Prinsip Pengembangannya. Bogor:PAU Pangan dan Gizi. IPB. 207 pp

Tazwir, Heruwati, E.S., Saleh, M., Murdinah, Ariyani, F., Noer, M. dan Sugiyono. 2000. Penelitian Preparasi Tepung Hidrolisat Protein Ikan (HPI) dari HPI Cair. Laporan Teknis Penelitian Preparasi Hidrolisat Protein Ikan (HPI) sebagai Bahan Fortifikasi Pangan. Jakarta: Instalasi Penelitian Perikanan Laut Slipi, Balai Penelitian Perikanan Laut, Puslitbangkan, p.13-26.

Venugopal, V. (1994). Production of fish protein hydrolysates by microorganisms. In Martin, A.M. (ed.) Fisheries Processing: Biotechnology Applications. London, Chapman \& Hall.:223-243.

Yu, S.Y. and Kaur, R. 1991. Development of fish biscuits from round scad (Decapterus Russelli Rupp.). Processed supplementary food from fish powder. Proceeding of IPFC Working Party on Fish Technology and Marketing, Yogyakarta, Indonesia, 24-27 September 1991. Rome: FAO: 305-313. 


\section{LAMPIRAN}

Tabel 3. Hasil analisis proksimat tik-tik yang difortifikasi HPI, surimi dan kontrol Table 3. Proximate value of tik-tik fortified by FPH, surimi and control

\begin{tabular}{lccccc}
\hline Perlakuan/Treatment & Air/Moisture (\%) & Abu/Ash (\%) & Lemak/Fat (\%) & Protein/Protein (\%) & Garam/Salt (\%) \\
\hline Kontrol/Control & 2.63 & 1.79 & 36.95 & 9.00 & 1.51 \\
Surimi/Surimi & 1.51 & 1.42 & 33.83 & 11.86 & 1.56 \\
HPl/FPH 5\% & 2.81 & 1.24 & 32.59 & 10.00 & 0.85 \\
HPI/FPH 10\% & 3.04 & 1.51 & 33.84 & 12.02 & 1.39 \\
HPI/FPH 15\% & 3.91 & 2.00 & 28.76 & 12.98 & 2.02 \\
HPI/FPH 20\% & 3.79 & 2.48 & 27.89 & 14.12 & 2.66 \\
HPI/FPH 25\% & 4.74 & 2.92 & 22.49 & 14.80 & 3.21 \\
HPI/FPH 30\% & 5.12 & 3.78 & 23.60 & 15.70 & 3.93 \\
\hline
\end{tabular}

Tabel 4. Nilai proksimat kue kering hasil fortifikasi HPI dan kontrol

Table 4. Proximate value of biscuit fortified by FPH and control

\begin{tabular}{lccccc}
\hline Perlakuan/Treatment & Air/M oisture (\%) & Abu/Ash (\%) & Lemak/Fat (\%) & Protein/Protein (\%) & $\begin{array}{c}\text { Karbohidrat } \\
\text { Carbohydrate } \\
\text { (by difference) }\end{array}$ \\
\hline Kontrol/Control & 6.72 & 1.98 & 18.30 & 11.56 & 52.60 \\
Strawberi/Strawberry & 8.32 & 1.85 & 22.18 & 13.07 & 50.31 \\
Kayu manis/Cinnamon & 6.73 & 2.83 & 22.44 & 13.05 & 51.59 \\
Coklat/Chocolate & 5.69 & 1.60 & 22.67 & 12.92 & 48.28 \\
\hline
\end{tabular}


